\title{
Tuberculosis in water buffalo (Bubalus bubalis) in the Baixo Araguari Region, Amapá, Brazil
}

\section{Tuberculose em búfalos (Bubalus bubalis) na região do Baixo Araguari, Amapá, Brazil}

\author{
Silvia Minharro ${ }^{1}$; Cristiane de Morais Alves²; Pedro Moacyr Pinto Coelho Mota ${ }^{3}$; \\ Elaine Maria Seles Dorneles ${ }^{4}$; Andrea Padilha de Alencar ${ }^{5}$; \\ Raimundo Magalhães dos Santos ${ }^{6}$; Bruno Meireles Leite ${ }^{7}$; Andrey Pereira Lage ${ }^{8 *}$
}

\begin{abstract}
Water buffalo are of great economic importance in Brazilian Amazonia, which has the largest herd in Brazil. Bovine tuberculosis caused by Mycobacterium bovis is a zoonotic disease that results in severe losses to water buffalo production. Although the disease has already been described in the country, data on the occurrence and distribution of bovine tuberculosis in water buffalo in Brazil is very scarce. The aim of this study was to determine the frequency of bovine tuberculosis in water buffalo in the Baixo Araguari River region of Amapá, Brazil. Thirty herds, randomly selected from the 41 herds of water buffalo in the region, were sampled. From those herds, 212 randomly selected water buffalo were subjected to the comparative tuberculin skin test. The proportion of Baixo Araguari River region herds that were positive for bovine tuberculosis was 50.0\% (95\% CI $31.3 \%$ to $68.7 \%$ ) and the proportion of animals that were positive was estimated to be $14.8 \%$ (95\% CI $7.8 \%$ to $21.9 \%$ ). Our results show that bovine tuberculosis is spread widely among water buffalo in the Baixo Araguari River region, which suggests that measures to control the disease should be undertaken in the region.
\end{abstract}

Key words: Brazilian Amazon. Comparative tuberculin skin test. Epidemiology. Mycobacterium bovis.

\section{Resumo}

A criação de búfalos é de grande importância econômica na Região Amazônica, que abriga o maior rebanho do Brasil. A tuberculose causada pelo Mycobacterium bovis é uma zoonose que leva a perdas severas na criação de búfalos. Apesar de já ter sido descrita no país, dados sobre a ocorrência e distribuição da

\footnotetext{
${ }^{1}$ Prof $^{\mathrm{a}} \operatorname{Dr}^{\mathrm{a}}$ em Ciência Animal, Escola de Medicina Veterinária e Zootecnia, Congregação Medicina Veterinária, Universidade Federal do Tocantins, UFT, Araguaina, TO, Brasil. E-mail: silviaminharro@yahoo.com.br

2 Fiscal Federal Agropecuário, Serviço de Saúde Animal, Ministério da Agricultura, Pecuária e Abastecimento, Belo Horizonte, MG, Brasil. E-mail: cristiane.morais@agricultura.gov.br

${ }^{3}$ Dr. em Ciência Animal, Escola de Veterinária, UFMG, Laboratório Nacional de Referência Agropecuária, Ministério da Agricultura,Pecuária e Abastecimento, Pedro Leopoldo, MG, Brasil. E-mail: pedrompcmota@yahoo.com.br

${ }^{4}$ Prof $^{a}$ Dr $^{\mathrm{a}}$ em Ciência Animal, Universidade Federal de Lavras, UFLA, Lavras, MG, Brasil. E-mail: elaine.dorneles@dmv.ufla.br

${ }^{5}$ Fiscal Agropecuário Federal, Laboratório Nacional de Referência Agropecuária, Ministério da Agricultura, Pecuária e Abastecimento, Pedro Leopoldo, MG, Brasil. E-mail: andrea.alencar@agricultura.gov.br

${ }^{6}$ Médico Veterinário, Agência de Defesa Inspeção Agropecuária - DIAGRO, Macapá, AP, Brasil. E-mail: raimundomagalhaes@ gmail.com

7 M.e. em Saúde Animal pela Universidade de Brasília, UnB, Fiscal Agropecuário Federal, Ministério da Agricultura, Pecuária e Abastecimento - MAPA, Brasília, DF, Brasil. E-mail: bmleite1@gmail.com

${ }^{8}$ Prof. Dr. em Bacteriologia, Escola de Veterinária, Universidade Federal de Minas Gerais, UFMG, Belo Horizonte, MG. E-mail: aplage@vet.ufmg.br

* Author for correspondence
} 
tuberculose em búfalos no Brasil são escassos. O presente estudo investigou a frequência de tuberculose em búfalos na região do Baixo Araguari, Amapá. Trinta rebanhos, selecionados ao acaso dentre os 41 que criam búfalos na região, foram amostrados. Destes rebanhos, 212 animais selecionados ao acaso foram submetidos à tuberculinização cervical comparativa. A frequência de rebanhos infectados na região do Baixo Araguari foi de 50,0\% (CI 95\%: 31,3\% to 68,7\%) e a frequência de animais infectados foi estimada em $14,8 \%$ (95\% CI: 7,8\% to $21,9 \%)$. Nossos resultados mostram que a tuberculose está amplamente distribuída em búfalos da região do Baixo Araguari, Amapá e que medidas de controle da doença devem ser implementadas na região.

Palavras-chave: Mycobacterium bovis. Epidemiologia. Tuberculinização cervical comparada. Amazônia brasileira.

Water buffalo (Bubalus bubalis) are very common in Brazilian Amazonia, where they have been raised for milk and meat because of their high level of rusticity and ability to adapt to flooding regions (VEIGA et al., 1996). Despite being more resistant than cattle to the conditions of the Amazonian region, water buffalo are still susceptible to several infectious and parasitic agents that also affect cattle (MOTA et al., 2002; FERREIRA, 2009; SILVA et al., 2014).

Mycobacterium bovis can also infect water buffalo, causing great economic losses when a herd is infected (HEINEMANN et al., 2008). Bovine tuberculosis in water buffalo has been described worldwide (MICHEL et al., 2010). Although it has also been reported in Brazil (PORTUGAL et al., 1971; MOTA et al., 2002; RIBEIRO et al., 2003), the data on its prevalence and distribution in different areas are very scarce, particularly in Brazilian Amazonia.

Since 2001, the Ministério da Agricultura, Pecuária e Abastecimento (MAPA) of Brazil started a national program for the control and eradication of brucellosis and tuberculosis (Programa Nacional de Controle e Erradicação de Brucelose e Tuberculose Animal - PNCEBT) in cattle and water buffalo (BRASIL, 2006). One major component needed for the establishment of control and eradication programs is knowledge of the disease status at the start of the program, to be used as a comparative parameter for the program's progress. Therefore, the aim of the present study was to determine the frequencies of individual water buffalo and herds that tested positive for bovine tuberculosis in the Baixo Araguari River region, Amapá, Brazil.

The Baixo Araguari River region, with an area of $17.996 \mathrm{~km}^{2}$, comprises three municipalities: Amapá, Tartarugalzinho, and Cutias (Amapá State, Brazil) (Figure 1) (IBGE, 2007). The major economic activity in the region is the raising of cattle and water buffalo, although water buffalo herds are gradually replacing cattle. Data from the animal health authority of the State of Amapá (Agência de Defesa e Inspeção Agropecuária - DIAGRO) revealed 41 water buffalo herds in the region, with a total population estimated at 23,000 .

DIAGRO conducted a survey on bovine tuberculosis in water buffalo from the Baixo Araguari River region, in 2005. Cluster sampling was carried out in two stages. First, 30 herds were randomly selected from the region's water buffalo herds. These properties were distributed in the municipalities of Amapá (10), Cutias (13), and Tartarugalzinho (7). Then, five to 14 adult female animals were randomly selected from each herd, for a total of 212 animals tested.

The selected animals were subjected to a comparative tuberculin skin test, as described by the PNCEBT for water buffalo (BRASIL, 2006), using avian and bovine tuberculin (Lanagro / MG, MAPA, Brazil). A herd was classified as positive if at least one positive animal was found. Animals with inconclusive tuberculin skin test results were considered negative. 
Prevalence and confidence intervals were calculated with data weighted by the herd size (BENNETT et al., 1991; NOORDHUIZEN et al., 1997). The confidence interval for herd prevalence was calculated using the exact Clopper-Pearson confidence interval for a single binomial proportion using the $\mathrm{R}$ package binGroup (ZHANG et al., 2011).

Figure 1. The Baixo Araguari River region (Amapá, Brazil), where water buffalo herds were selected and animals were subjected to the tuberculin skin test, 2005.

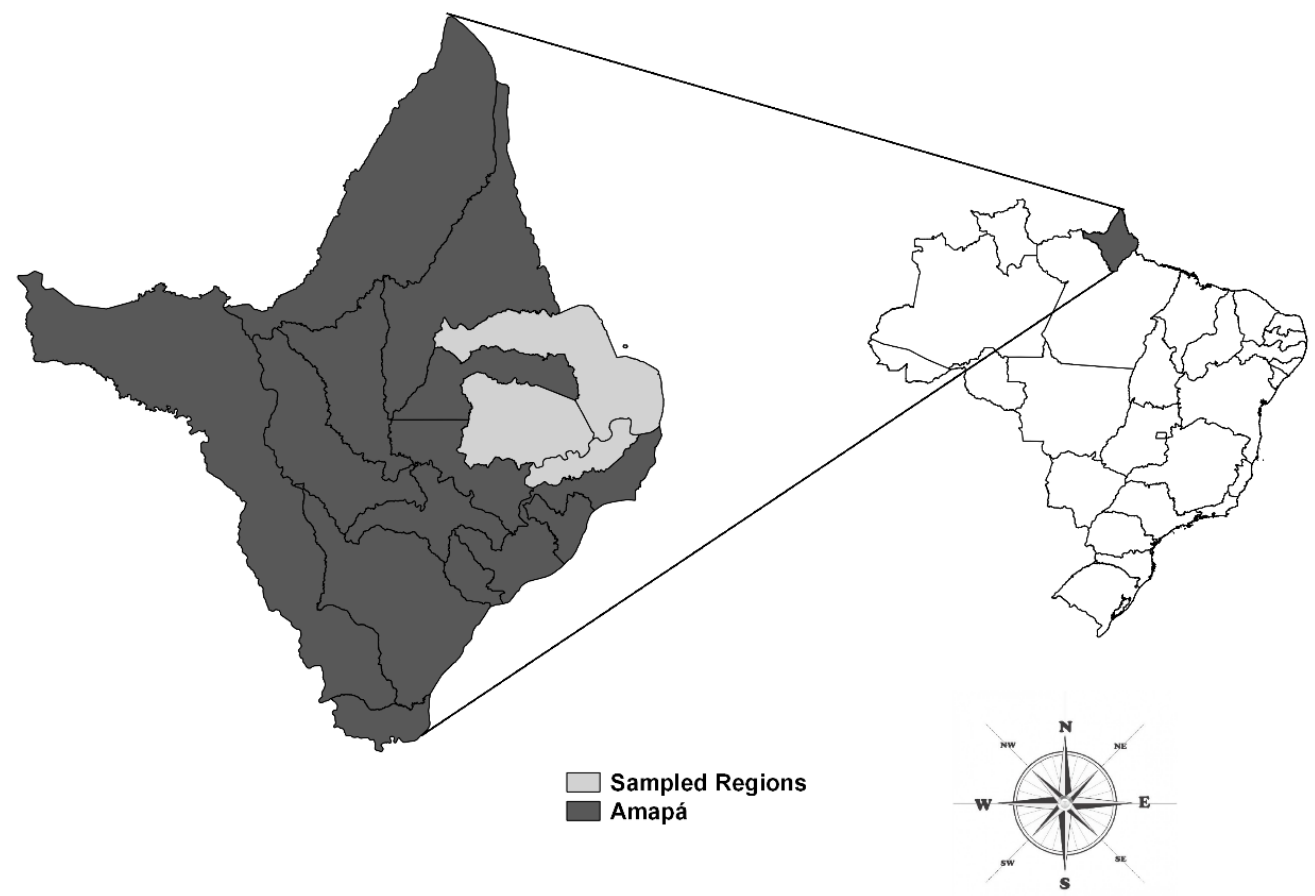

Of the 212 animals tested, 31 had positive, 29 had negative, and 152 had inconclusive comparative tuberculin skin test results. Fifteen of the studied herds had bovine tuberculin-reactive animals. The frequency of bovine tuberculosis in water buffalo in the studied region was estimated as $14.8 \%(31 / 212)$ (95\% CI $7.8 \%$ to $21.9 \%$ ) for individual animals and $50.0 \%$ (15/30) (95\% CI $31.3 \%$ to $68.7 \%)$ for herds.

Similar frequencies of tuberculin-positive water buffalo have been observed in the Amazon region [20.4\% (266/1303)] (MOTA et al., 2002). However, the number of tuberculin-positive animals observed in the Baixo Araguari River region was higher than in São Paulo (6.0\%) and Maranhão [13.5\% (21/155)], Brazil (PORTUGAL et al., 1971; PEREIRA et al., 2009), which could be due to differences in time and sampling location. Another study involving bovine tuberculosis in water buffalo in Parintins (Amazonas, Brazil) also observed a high prevalence of infected animals (20.4\%) and an even higher prevalence of infected herds, since the disease was diagnosed in all water buffalo herds analyzed (MOTA et al., 2002).

The high frequency of tuberculin-positive water buffalo found in Brazilian Amazonia could be due to the way animals are raised in the region. Although almost all herds are raised using extensive production systems, during the rainy season when most of the area is flooded, animals are confined to very small feeding areas or are even raised on ships. Such high density can increase the likelihood of the spread of the disease, since close contact 
with infected animals is recognized as one of the major risk factors for the transmission of bovine tuberculosis (HEINEMANN et al., 2008; MICHEL et al., 2010).

The occurrence of bovine tuberculosis in water buffalo found in the present study may have been much higher than the estimated number because we decided to use a more specific cutoff by considering the animals with inconclusive results as having negative test results. Furthermore, anergy is a concern in the diagnosis of bovine tuberculosis; thus, some infected animals could show negative reactions to the tuberculin skin test (MONAGHAN et al., 1994). Nevertheless, those inconclusive reactions could also be the result of direct contact or infection of the water buffalo by Mycobacteria other than tuberculosis (MOTT) (MONAGHAN et al., 1994). There have already been reports of the isolation of MOTT from the caseous material of water buffalo from the Brazilian Amazon (RIBEIRO et al., 2003), which could lead to inconclusive or false-positive tuberculin skin test results. However, the comparative tuberculin skin test used in this study helped to prevent false-positive results due to contact with MOTT (MONAGHAN et al., 1994).

The high prevalence of bovine tuberculosis in water buffalo is of great concern for the Brazilian Amazon, where this species is economically very important (VEIGA et al., 1996; LOURENÇO JÚNIOR, 1998). Moreover, it is a major public health concern (MICHEL et al., 2010), since water buffalo milk and meat are essential in the diet of the region's population.

Control measures (BRASIL, 2006; HEINEMANN et al., 2008) based on culling infected animals and reducing chief risk factors, such as a high density of animals during the flooding season, should be implemented in the region. Alongside these measures, the establishment of an education program targeting the breeders and explaining the public health risk of contact with infected animals and the consumption of infected milk or meat would be worthwhile.

Our results show that bovine tuberculosis is spread widely among water buffalo in the Baixo Araguari River region of Amapá, Brazil. Measures to control the disease should be undertaken in the region.

\section{Acknowledgements}

This study was supported by Conselho Nacional de Desenvolvimento Científico e Tecnológico CNPq, Fundação de Amparo à Pesquisa do Estado de Minas Gerais - FAPEMIG, and Fundação de Estudo e Pesquisa em Medicina Veterinária e Zootecnia - FEP-MVZ. EMSD and APL are indebted to Conselho Nacional de Desenvolvimento Científico e Tecnológico - CNPq for the fellowships received.

\section{References}

BENNETT, S.; WOODS, T.; LIYANAGE, W. M.; SMITH, D. L. A simplified general method for cluster sample-surveys of health in developing countries. World Health Statistics Quaterly, Genebra, v. 44, n. 3, p. 98106, 1991.

BRASIL. Manual técnico do programa nacional de controle e erradicação da brucelose e da tuberculose PNCEBT. Brasília: Ministério da Agricultura, Pecuária e Abastecimento, Programa Nacional de Controle e Erradicação da Brucelose e Tuberculose MAPA/DSA/ DAS, 2006. 184 p.

FERREIRA, R. N. Prevalência da Rinotraqueite Infecciosa Bovina (IBR) em touros bubalinos em propriedades localizadas no Amapá e Ilha de Marajó (PA), Brasil. 2009. Dissertação (Mestrado em Ciência Animal) - Universidade Federal do Pará, Belém.

HEINEMANN, M. B.; MOTA, P. M. P. C.; LOBATO, F. C. F.; LEITE, R. C.; LAGE, A. P. Tuberculose bovina: uma introdução à etiologia, cadeia epidemiológica, patogenia e sinais clínicos. Cadernos Técnicos de Veterinária e Zootecnia, Belo Horizonte, v. 59, p. 1-12, 2008. 
INSTITUTO BRASILEIRO DE GEOGRAFIA E ESTATÍSTICA - IBGE. Banco de dados agregados, 2007. Brasília: Instituto Brasileiro de Geografia e Estatística, 2007. Disponível em: <http://www.sidra. ibge.gov.br/dba/acervo>. Acesso em: 20 nov. 2013.

LOURENÇO JÚNIOR, J.B. Variáveis produtivas, fisiológicas e de comportamento de zebuínos e bubalinos e fatores do ambiente físico em pastagem cultivada da ilha de Marajó. 1998. Tese (Doutorado em Ciências Biológicas) - Curso de Pós-Graduação em Ciências Biológicas, Universidade Federal do Pará.

MICHEL, A. L.; MÜLLER, B.; VAN HELDEN, P. D. Mycobacterium bovis at the animal-human interface: a problem, or not? Veterinary Microbiology, Amsterdam, v. 140, n. $3-4$, p. 371-381, 2010.

MONAGHAN, M. L.; DOHERTY, M. L.; COLLINS, J. D.; KAZDA, J. F.; QUINN, P. J. The tuberculin test. Veterinary Microbiology, Amsterdam, v. 40, n. 1-2, p. 111-124, 1994.

MOTA, P. M. P. C.; LOBATO, F. C. F.; ASSIS, R. A.; LAGE, A. P.; PARREIRAS, P. M.; LEITE, R. C. Ocorrência de tuberculose em rebanhos bubalinos (Bubalus bubalis var. bubalis-Linneus, 1758) no Município de Parintins, Amazonas. Arquivo Brasileiro de Medicina Veterinária e Zootecnia, Belo Horizonte, v. 54, n. 4, p. 441-443, 2002.

NOORDHUIZEN, J. P. T. M. Application of quantitative methods in veterinary epidemiology: enfield pub \& distribution company. Holanda: Wageningen Pers, 1997. 443 p.
PEREIRA, H. M.; SANTOS, H. P.; BEZERRA, D. C.; ARAGÃO, A. C. C.; SOUSA, V. E. Ocorrência de tuberculose em rebanho bubalino (Bubalus bubalis VAR. BUBALIS-LINNEUS, 1758) em uma propriedade do município de Arari, Maranhão, Brasil. Ciência Animal Brasileira, Goiânia, p. 546-550, 2009. Suplemento 1.

PORTUGAL, M. A. S. C.; GIORG, W.; SIQUEIRA, P. A. Ocorrência de tuberculose em bubalinos (Buballus bubalis var. Bubalis lineus, 1758) no Estado de São Paulo. Arquivos do Instituto Biológico, São Paulo, v. 4, n. 1, p. 231-238, 1971.

RIBEIRO, A. R. P.; LOBATO, F. C. F.; ABREU, V. L. V.; FARIA, E. S.; SILVA, J. A. Prevalência de tuberculose e brucelose bovina no município de Ilhéus. Arquivo Brasileiro de Medicina Veterinária e Zootecnia, Belo Horizonte, v. 55, n. 1, p. 120-122, 2003.

SILVA, J. B. D.; ALBUQUERQUE, C. T.; SOUZA, M. G. S.; GIBSON, A. F. B.; VINHOTE, W. M. S.; FONSECA, A. H.; ARAÚJO, F. R.; BARBOSA-NETO, J. D. Detecção sorológica e molecular de Anaplasma marginale em búfalos na Ilha de Marajó, Pará. Pesquisa Veterinária Brasileira, Rio de Janeiro, v. 34, n. 1, p. 11-14, 2014.

VEIGA, J. B.; TOURRAND, J. F.; QUANZ, D. $A$ pecuária na fronteira agrícola da Amazônia: o caso do município de Uruará, PA, na região da Transamazônica. Belém: Embrapa-CPA TU, 1996. 61 p. (Embrapa-CPA TU. Documentos, 87).

ZHANG, B.; BILDER, C.; BIGGERSTAFF, B.; SCHAARSCHMIDT, F. BinGroup: evaluation and experimental design for binomial group testing. Hannover: Frank Schaarschmidt, 2011. Available at: $<$ http://CRAN.R-project.org/package=binGroup $>$. Accessed at: 12 sep. 2012. 
